\title{
ANALYSIS OF HEALTH POLICY IN THE BORDER AREA OF WEST KALIMANTAN INDONESIA
}

\author{
Abil Rudi* \\ Institute of Health Science Kapuas Raya Sintang, West Kalimantan, Indonesia \\ abilrudistg@gmail.com
}

\begin{abstract}
Background : The health status of the people in the border areas with low economic level, especially in rural areas, have not received equitable health services optimally due to geographical location, infrastructure and social. In addition, the border area with vast areas still found the lack facilities and infrastructure of hea lth services that will be make people in the border area is still low in accessing health care facilities. On the other hand, the health workers who are not willing to be placed in the border area has a big influence and that's lowering the community health status. Problems of inequality health efforts in the border area also caused by the socioeconomic status of the local community which is poverty so that can't access the health services. Objective : This study aims to analyze the implementation of health policies in the border areas in West Kalimantan, Indonesia. Method : This study is a descriptive study with qualitative approach. This study is a literature study research. Results : Health policy in border area has not been able to overcome the problems of the spread of health workers in the border area. Policies on the health insurance system in the border areas are not distributed optimally. Policies on basic health infrastructure in border areas have not been equally distributed. Policies on referral transportation in border areas are not yet sufficient. Conclusion: The implementation of health policies in the border areas have not been fit for the purposes to increase health status for community.
\end{abstract}

Keywords : health policy, border area, West Kalimantan

\section{Background}

Health development continue to be improved by the government, especially in the Border Remote Area, mainly directed at the area of eastern Indonesia. Health development activities towards the Universal Coverage 2019 , with priority programs to achieve the expansion of health coverage, equitable access to health services, adequate health facilities in Boerder Remote Areas, and increasing promotive, preventive and disease mitigation $^{(1)}$. Health development in particular on the Border Remote Area, explicitly in the Decree of the Minister of Health of the Republic of Indonesia Number : 331/Menkes/SK/V/2016 about Health Strategic Plan 2005-2019 (2). 
The goals of health development are to facilitate the community in accessing health services and equitable distribution of qualified health services in Border Remote Areas. Health services have become an important industry, with a mix of public and private non-profit and for-profit actors, along with the growth of trade and medical tourism ${ }^{(13)}$. In facilitating the access and equity of health services, the Ministry of Health has drawn up a plan of action and development, namely: 1) Mobilizing and empowering communities in Border Remote Areas, 2) Improving access of community in Border Remote to qualified health care, 3) Improving health care financing in Border Remote Areas, 4) Improving the skill of health workers in Border Remote Areas, 5) Increasing the availability of medicines and supplies and, 6) Improving the management of health centers in Border Remote Area, including surveillance system, monitoring and evaluation, and Health Information systems $^{(1,3)}$.

West Kalimantan is one of the provinces in Indonesia which is directly bordering Serawak Malaysia. The border areas including Badau, Puring Kencana, Senaning and Entikong. The border area is a storefront of a country. Besides, the Border Remote Areas has geographically distant from urban areas, and have problems of road infrastructure and low economic levels. Another issue in Remote Border Areas are the lack availability of public health facilities and infrastructure, and lack of health workers.

The National Health Insurance (in Indonesia, called Jaminan Kesehatan Nasional) beginning in 2014 which was held by the Agency for the Implementation of the Social Security (Badan Penyelenggara Jaminan Sosial/BPJS) and the enactment of Law No. 24/2011 about BPJS. The National Health Insurance gradually toward Universal Health Coverage in accordance with the road map to Health Insurance in $2019^{(4)}$. Generally, the purpose of the National Health Insurance is to facilitate community for accessing health services and getting qualified health services. Universal Health Coverage is a very good thing, but probably havesome impacts.Inequal availability of health facilities, health workers and geographical conditions, causeda huge gap of qualified health services between provinces and the Border Remote Areas.

Ministry of Health develop an action plan to be applied in the field, there areincreasing the skillof non-permanent health workers, giving permission to health workers to continue their study, and adding the availability of transportation in Border Remote Areas ${ }^{(3)}$. Whereas in 2016, the Ministry of Health and Ministry of Utilization of State Apparatus and Bureaucracy Reform will recruitthe non-permanent health workers become civil servant in order to supply the needs of health workers in health centers in Border Remote Areas ${ }^{(5)}$. However, however, it is not always accompanied by the readiness 
of health workers to be placed and serve in the border area.

Based on the situation, the authors are interested to conduct a study on the analysis of health policy in the border areas of West Kalimantan.

\section{Methods}

This research is descriptive qualitative approach, to analyze health policies border area in Kapuas Hulu District, there are Badau and Puring Kencana, in Sintang District there are Senaning, and in Sanggau District, there is Entikong, West Kalimantan Province. This study is literature review. The author performed the analysis of documents/policies, news, websites and any literature associated with the research topic.

\section{Results and Discussion}

\section{Equitable Health Workers in the Border} Areas

Equitable Health Workers in the Border often be a problem. This is due to the vast area of health centers in the border area so that the health workers difficult to reachthe community in its work area. The recruitment of health workers, especially non-permanent doctors, with a year contract period and its incentive pattern is not optimal yet, as well as health workers are still concentrated in urban areas ${ }^{(6)}$.

Health workers, especially civil servant doctors, as head of the health center which has larger duty and responsibility but get less reward than the non-permanentdoctor with less responsibility and fewerexperience. Sustainability of non-permanent doctors are often interchangeably since the contract period is only one year, thus affecting the management systems and affecting the quality of health services in health centers. Also, there are more health workers in urban areas compared to border areas. The low level of patient visits to health centers in the border area proved the difficulty people to access health services related with a geographical location. Lack of transportations and low capability to pay for the cost of transportations also contributed to the low level of patients visit.

People in border areas expect health workers from health center perform home visit or closer with them. Therefore, people tend to call the health workers, especially nurses and midwives, to come to their home because they consider the cost of calling the health workers come to their home is same with the cost if they come to health center. This situation shows that health workers are less effective in performing their duties. It is supported by research that conducted by Wasis et al (2007) that $32.9 \%$ of working time nurses are not effective, while a midwife is approximately $\quad 43.09 \%$ work less effective $^{(7)}$. Planning of health workers needs in the health center should be done with macro and micro level analysis. Macro-level analysis helps to know how 
many personnel needed and micro level analysis will determine the type of health workers that should be recruited ${ }^{(8)}$.

\section{Health Insurance System in the Border Area}

The National Health Insurance (JKN) beginning in 2014 which was held by the Agency for the Implementation of the Social Security (BPJS) and the enactment of Law No. 24/2011 about BPJS. The National Health Insurance (JKN) gradually toward Universal Health Coverage in accordance with the road map to Health Insurance $2019^{(4)}$. The general purpose of the National Health Insurance is to facilitate community for accessing health services and getting qualified health services.

The results showed that the observation of one of the villages in the border area of a total of 50 families, only 8 families who get National Health Insurance $(\mathrm{JKN})$ freelyfrom the government, in this case is from BPJS. The results of interview to the chief of village found that the local community never get the socialization about health insurance from related parties. Therefore, the people in the border areas have not gotten the National Health Insurance (JKN) equally. Inequality of National Health Insurance (JKN) in the border areas will have an impact on the occurrence of health care disparities between regions in Indonesia, especially in border areas.

\section{Basic Health Facilities and Infrastucture in Border Area}

Health infrastructure in border area is inadequate, it's caused by the supportive infrastructure in health center, such as laboratory, still incomplete and could not satisfied the community. Besides, the medicine in health center is incomplete and often out of stock. The result of observation showed that some tools in health center, such as spignomanometer, is not suitable to be used. Then, the emergency tools, such as oxygen tube, there is only one provided and often no oxygen inside.

This is supported with research conducted by Ristrini et al, (2004) and Handayani et al, (2006) shows that the medical equipment in health center is still not sufficient. The number of emergency cases require special equipment and skills, but in reality is still lacking. Because primary health center is the first provider to handle emergency cases, so the provision of emergencies equipment should be available at all primary health care (PHC). Besides, skills of health workers who are responsible at the health centershould be improved $^{(9,10)}$.

\section{Referral Transportation in Border Areas}

The referral transportation is very limited and high costly, whether in land or river areas. At the primary health care (PHC), only provided one ambulance. Use of referral transportation only used when a 
patient requires further treatment to the secondary level at the hospital which is located in the capitaldistrict. Patients who do referrals to hospitals often not accompanied by health workers from health centers.

The problems of health care in border areas can be addressed by an integrated health care. Integrated health system is divided into two approaches, institutional approaches and systems approach $^{(12)}$. The contributors who can make the integrated health care goes well is the government, technology and transportation $^{(11)}$. Government tried to solve the transportation problem with empower the community through a program named Desa Siaga. Desa Siaga is a village that has a readiness and ability to prevent and handle health problems (such as disasters and health emergencies) independently ${ }^{(1)}$.

\section{Conclusions and Recommendations Conclusion}

1. Health workers in the border area have not been able in providing optimal health service to the community.

2. Health insurance in the border areas are not evenly distributed optimally.

3. The availability of health care facilities and infrastructure in border areas is still not provided well.

4. The referral transportation system in primary health careis not run properly.

\section{Recommendation}

1. Increase the number of health workers in the border areas and provide more intensive qualified training for health workers in border areas.

2. Socialization about national health insurance $(\mathrm{JKN})$ on communities in border areas should be implemented more intensive and increase the number of national health insurance card (JKN) receiver in border areas.

3. Fulfillment of the availability of facilities and infrastructure of health services in health centers in the border area, at least same level as with the neighboring country's health services.

4. Adding transportation health facilities in the border areas with the provision of a referral based transportation maximally.

\section{Bibliography}

1. Ministry of Health. Roadmap Reformasi Kesehatan Masyarakat. The Ministry of Health of the Republic of Indonesia. Jakarta. 2010.

2. Ministry of Health. Keputusan Menteri Kesehatan Republik Indonesia Nomor : 331/MENKES/SK/V/2016, tentang Rencana Strategis Kementerian Kesehatan Republik Indonesia tahun 2005-2019. The Ministry of Health of the Republic of Indonesia. Jakarta. 2006.

3. Ministry of Health. Pedoman Pelayanan Kesehatan di Puskesmas Terpencil dan sangat Terpencil di Daerah Tertinggal Perbatasan dan Kepulauan. The Ministry 
of Health of the Republic of Indonesia. Jakarta. 2010.

4. GTZ, AusAID. Peta Jalan Menuju Jaminan Kesehatan Nasional 2012-2019. Compiled together and supported by GTZ, AusAID. Jakarta. 2012.

5. Ministry of Health. Badan Pengembangan dan Pemberdayaan Sumber Daya Manusia Kesehatan. The Ministry of the Republic of Indonesia. Jakarta. 2015.

6. Dwiyanto. Masalah Mendasar Pelayanan Kesehatan Di Indonesia. http://fdwiyanto. blogspot.co.id/2011/10/masalah-mendasarpelayanan-kesehatan-di.html. 2011

7. Wasis B, Agus Suprapto, Ristrini. Studi Tentang Rekrutmen, Seleksi dan Alokasi Kegiatan tenaga Keperawatan di Daerah Terpencil di Jatim dan NTT. Badan Penelitian dan Pengembangan Sistem dan Kebijakan Kesehatan. Buleten Health Systems Research. Vol. 10 No. 2. Surabaya. 2007.

8. Rienke, William A. Personil dalam Perencanaan Kesehatan untuk Meningkatkan Efektifitas Manajemen. Yogyakarta: Gadjah Mada University Press. 1994.
9. Hand L, Evie S, Siswanto, et al. Upaya Revitalisasi Pelayanan Kesehatan Puskesmas dan Jaringannnya dalam Rangka Peningkatan Kualitas Pelayanan Kesehatan. Badan Penelitian dan Pengembangan Sistem dan Kebijakan Kesehatan. Buleten Health Systems Research. Surabaya. 2006.

10. Ristrini, Sulistyowaty, Siswanto, et al. Intervensi Pemberdayaan Masyarakat Melalui Penumbuhkembangan Upaya Kesehatan yang Berbasis Masyarakat Miskin di Pedesaan dalam rangka Making Pregnancy Safer. Badan Penelitian dan Pengembangan Sistem dan Kebijakan Kesehatan. Buleten Health Systems Research. Surabaya. 2004.

11. L. Sheppard What the People WantDelivery of Health Services in Rural and Remote Australia. The Internet Journal of Allied Health Sciences and Practice. 2005.

12. Anwar, A. Pengantar Administrasi Kesehatan, Edisi Ketiga, Binarupa Aksara. Jakarta. 1996.

13. Hongsranagon, Prathurng. Helath System Reforms in Malaysia, Thailand and indonesia ; A historical Perspective. Charansanitwong Prining. Bangkok. 2015 